\title{
THE ROLE OF COMPANY IN SUPPORT OF THE INCLUSIVE GROWTH IN THE CONTEXT OF EUROPEAN UNION GOALS
}

\author{
Ivana Šidová ${ }^{1}$, Anna Vallušová ${ }^{2}$ \\ ${ }^{1}$ Univerzita Mateja Bela, Ekonomická fakulta, Tajovského 10,975 90 Banská Bystrica, SR \\ Email:ivana.sidova@umb.sk \\ ${ }^{2}$ Univerzita Mateja Bela, Ekonomická fakulta, Tajovského 10,975 90 Banská Bystrica, SR \\ Email:anna.vallusova@umb.sk
}

\begin{abstract}
Inclusive growth, which is stressed as a priority for strategy Europe 2020, could be achieved by application of flexicurity approach in employment policy. One of the four flexicurity components is lifelong learning, which is an important part of employee's education in the company. In this context, the aim of the article is to define the role of company in eliminating labor market rigidity, which is essential for social inclusion on the basis of the analysis of the EU strategies in this area. Because the decision on the extent and quality of employee's education in the company is fully in the competence of company, we also emphasize the necessity of the perception of corporate social responsibility as a characteristic that enhances business social function and from the long perspective shape a qualitatively new ground of company's existence.
\end{abstract}

Keywords: corporate social responsibility, education, Europe 2020, flexicurity, inclusive growth.

JEL classification: J24, M53

Doručeno redakci: 27.6.2012; Recenzováno: 18.12.2012; 8.1.2013; Schváleno k publikování: 13.3.2013

\section{Introduction}

The European Union is currently facing important changes. Continuing globalization, emerging competition, technological changes, environmental problems and aging population are putting strong pressure on the need of changes in the way of managing state economy but also the whole country. In addition to these changes the global economic crisis affects all decisions in the state and its consequences are still present also after overcoming its most difficult phase. In this context, the aim of the article is to define the role of company in eliminating labor market rigidity, which is essential for social inclusion, on the basis of the analysis of the EU strategies in this area. In the first part we will discuss strategies and initiatives of the European Union, which it has launched to face the mentioned changes with emphasis on the labor market. In the next section we will discuss the role of company in meeting this strategy. Finally, we will discuss tools to support the involvement of companies in the strategy of the European Union.

\section{Strategy Europe 2020 - new quality of growth}

European Union adopted strategic document Europe 2020 with the aim to react on new challenges mentioned in the introduction. According to this document adequate response will be achieving new quality of economic growth, whose main characteristics are:

- intelligent growth - the development of economy based on knowledge and innovations;

- sustainable growth - support of the economy, which is more ecologic and more competitive and which use existing sources more effectively;

- inclusive growth - creating of economy with the high level of employment which is delivering economic, social and territorial cohesion.

For the labour market the strategy of the inclusive growth is essential, because it includes also strengthening the role of citizen through the high level of employment, investments in skills, 
fight against poverty and the modernization of the labour markets, education systems and the social protection. The main goal of these investments is to help people to predict and to manage the changes and to create the cohesive society.

\section{Flexicurity - approach supporting the inclusive growth}

In the strategy Europe 2020 is stated that the crucial part in the field of the inclusive growth will be applying flexicurity approach which enables people to get new necessary skills necessary for adopting on changed conditions and possible career changes. T. Wilthagen and F. Tros (2004) defined flexicurity as a politic strategy that attempts, synchronically and in a deliberate way, to enhance the flexibility of labour markets, the work organization and labour relations on the one hand, and to enhance security - employment security and social security - notably for weaker groups in and outside the labour market on the other hand. For the first time the flexicurity was used as a part of the strategy within employment policy in $90^{\text {th }}$ years of the $20^{\text {th }}$ century in Denmark during the government of Prime Minister Poul Nyrup Rasmussen. Realization of this strategy brought to Denmark positive results and it inspired many states for launching modified flexicurity strategies. Since 2006, higher attention is paid to flexicurity while creating economic policy in the field of employment, because the European Commission identified flexicurity as an integrated approach which aims to reach the Lisboan strategy goals. The main aim of flexicurity is to create more quality jobs with the combination of various forms of flexibility and security. The reason for applying this approach would arise from the real changes in behaving and decision making of economic subjects on the labour market with particular emphasis on companies and individualities. Flexicurity approach focuses on four flexicurity components: the conditions of employment contracts, lifelong learning, active labour market policies and modern social protection.

The first component is conditions of employment contracts which aim to enhance required flexibility on the labour market. Z. Potužáková and S. Mildeová (2011) declare that in the EU the legislative of the fixed-term contracts has changed only. The reforms of the legislative of the open-ended contracts have not been realized. It caused the dualization of the labour market, where two groups of employees with the asymmetric position and different form of legislative protection rose. The first group includes the employees with the open-ended contracts. These employees are considered as crucial employees and therefore they have all advantages, which the employer offers to the employees. The second group consists of the employees with the fixed-term contracts. The disadvantage of fixed-term employment contracts is the fact, that these employees do not have the same rights as the employees with open-ended contracts. The employees with the fixed-term contracts are often not involved in trainings, which are realized in the company. At the same time there is not offered the same benefits for the employees with fixed-term contracts in comparison with the employees with open-ended contracts. The fixed-term contracts are still considered as intermediate stage between unemployment and open-ended contracts. Only the open-ended contracts are considered by employees as worthy job offering sufficient securities for personal life planning. Also S. Fredman (2004) points out this danger, when he declares that the number of fixed-term will only increase in the case when the rights of both groups of employees would be the same. In this area the flexicurity focuses on the equalization of rights of the both groups of employees and then it prefers to use the fixed-term contracts, because of the enhancing company's flexibility. The necessary condition for the more frequent use of fixedterm contracts is the security, that in the case of loss of employment the person does not fall in the group of people endangered by poverty and the functioning security system provides the people with the help during the time of looking for a new job. 
Nowadays, the skills and knowledge which we have learned as the pupils and later as the students at school are not sufficient for the whole life. Very important is the individual motivation to learn. That is why the complex lifelong learning strategies were chosen as a second component of flexicurity. According to A. Greiner and P. Flaschel (2009) flexicurity approach motivates the employees to broaden and deepen their education, because the employees try to increase their employment security in the case of losing their current job and besides new knowledge they get also skills which they can use in the praxis. With the further education they try to increase their competitive ability which they use in labour market while looking for a new job and it also strengthens the level of perceived employment security. This conclusion is also confirmed by the study of M. Belot, J. Boone and J. van Ours (2007), which focuses on analysis of job protection level in the European countries. The results of the study show that more educated employees have a job with signs of higher level of job protection. Also the employees have higher positive preferences to the conclusion that regular education strengthens their job possibilities. The higher education can be also the reason for higher salary especially when the employee brings new ideas to company or there is growth of work productivity. The new field within the flexicurity is offering the education possibilities for all employees, it means also for fixed-term workers. This way is one of the possibilities to grant equal rights for all employees in the company and it is related to effort of more frequent use of fixed-term employment contracts as a tool for increasing flexibility in the company and also on the labour market.

The third component of flexicurity is active labour market policy. According to M. Uramova (2004) the current tendencies in employment policy in Slovakia is to move the focus from unemployment to employment, from passive protection of unemployed to active support by creation of the new jobs and by increasing of people's adaptability, from the enormous and ineffective state regulation to higher liberalization and flexibilization of labour market. The aim of the active labour market policy is to offer the measures which should make the comeback to job easier but also to shorten the duration of unemployment with the appropriate supporting and motivating tools. S. Cazes and A. Nesporova (2007) declare that although active labour market policy has only limited possibilities to create new jobs directly, its main task is to broaden the labour supply on the labour market, to improve her quality, to provide help by copying with changes on the labour market and to reduce inequalities on the labour market. The active labour market policy is especially important for low-income labour force, which became expensive on the labour market because of increasing minimal wage. The result of the active labour market policy should be the increase of ability to hire the labour force and in this way to improve functionality of the labour market with it. The next aim of the active labour market policy is to decrease the level of the long-lasting unemployment because unemployed people lose their work habits after longer time but there occurs also obsolescence of qualification and they became useless for the labour market's needs. By involving this component in the flexicurity approach, the duration of unemployment is shortened, but it also provides help by overcoming the unemployment and at the same time it increases income security. S. Cazes and A. Nesporova (2008) emphasize that the extent of active labour market policy should be widen for everyone, who is looking for a job and provide them with the assistance until they will find the new job. The active labour market policy raises the level of perceived employment security and at the same time supports the ability to find a new job.

Modern social security systems are the fourth component of flexicurity approach. The main task of social security system is to prevent, soften and remove the implications of social incidents. Into social security system we can involve also the benefit during unemployment, 
which is for many citizens very important. The benefit during unemployment represents for most people the only income for the duration of unemployment and it enables to overcome this time. The economists find liquidation of workplace to be a part of innovation and growth process. But for most employees losing job means very hard period in life, which they try to solve as soon as possible. I. Dudova, A. Oskova and P. Stanek (2008) declare that flexicurity tries to improve the effectiveness of employment policy without reduction of social benefits. The level of social benefits should be appropriate to living costs and it should help the unemployed people not to fall into danger of poverty. On the other hand they should not allow to stay unemployed for a long time. It should be motivation factor for looking for a job.

Although the flexicurity approach is presented as an economic-politic approach to employment policy, it is necessary to study possibility of its application and modification for particular conditions in a country. From this point of view we can see three stages of flexicurity approach. The first stage is macroeconomic and it involves the decision making on level of government and international institution. The second stage is microeconomic and the decision making is on the level of collective bargaining in company or in state. The third level is company level and the flexicurity approach is presented as mutual agreement between employer and employee. In some publication is presented also the forth level and it is individual. It is represented by an effort for improvement of communication between work and free time of individuals. From our point of view this level is part of third level, where the employee has his place and he tries to combine work and family life.

\section{The role of a company}

It is certain that the flexicurity approach described above needs the cooperation of wide range of subjects, mainly the companies. The economists have been discussing for many decades the fact if it is in the interest of society to involve companies in other fields than producing of goods and services and maximisation of profit within the range of legal regulations. The beginning of these discussions we can date back to "the father of the economics" A. Smith (1776, p. 125) who declared that "by pursuing his own interest, an individual frequently promotes the welfare of the society more effectually than when he really intends to promote it".

Also M. Friedman (1970) followed up the ideas of A. Smith. Friedman doubted whether the initiative of companies to contribute to elimination of negative social phenomena is not destroying the foundations of free society. He argued that the managers who decide for "social responsible activities" of company act in the same way as the state. They impose taxes on the incomes of company owners and they use them for the purposes which they themselves consider to be necessary. The difference in comparison to state is in the fact that the managers are in this decision making in the same time the legislative, executive and judicial power.

In the context of the labour market and the flexicurity approach it is expected that companies are involved into the issue of employability of persons. Its concrete form in this case should be lifelong learning of employees, according to the fact that knowledge and skills are a key factor to reach the employment security on the microeconomic level. At the same time this approach stresses the equalization of all employees: with the fixed-term contracts and also with the open-ended contract. Here we can agree with the A. Smith that this education is going to run effectively only if the companies follow their own interests and not the interests of society. That is why the question arises if it is necessary to study the education from the perspective of society and what role the economic theory has in this case. 
In general we can use one of the three methodological approaches (T. Donaldson and L. E. Preston, 1995):

- normative approach - the theory interprets only the function of the company in society and it gives us moral and philosophic guidelines of company's operations;

- instrumental approach - the theory identifies on the one hand the connection and on the other hand the lack of connection between the activities in favour of the whole society and fulfilment of the company aims, in the most cases maximization of revenues or the market values of company;

- descriptive approach - the task of the theory is to describe and explain the behaviour of the companies, in our case also the role of the company in the society and its relationship to its surrounding.

We are convinced that it is necessary to focus on descriptive approach to this issue; so it is necessary to search "what we can do, instead of what we have to do" (Horehajova Marasova, 2008, p. 58). This view is in contrary to doubts of M. Friedman who used the normative approach to this issue.

Undeniable, in this context, is also the fact that the primary incentive of companies to invest into education of employees has economic character; it means the companies try to increase their performance through qualified labour force. We can consider this investment to be effective when the financial effects are higher than resources invested. In the field of human resources management there is not any correlation between the height of investments to human capital and the profit resulting from it. The employees engage themselves in the work process by providing their human capital to their employers, but it still remains their property. The company should create such conditions in which the capital is released. This is possible only when the employee accept the created conditions (Neumaierova, Neumaier, 2002). Therefore, it is useful to perceive also the surrounding and the context, in which the company realizes its activities. On the one hand, it enables company to identify the conditions, which are motivating for the employees. On the other hand, it is necessary to perceive the fact that crucial aspect of responsible behaviour is the mutual responsibility. Therefore it is necessary that the employees too perceive the education in broader context, not only as the obligation to employer but also as the extension of their qualification and their employability.

Therefore, it is necessary to seek systems and principles of management which transforms the individual responsibility of owners, managers and employees to the responsibility of the organization. It means searching for synergic solutions that contribute in the same time to development of a company and to development of society. What kind of the solution? L. Knippenberg and E. de Jong (2010) describe them as follows. The company can maintain good performance in the long run only on condition that it formulates, implements and adopts a strategy that will help it to gain a competitive advantage difficult to reproduce. To achieve this state, there are generally two approaches. The first approach represents a well-known Porter five forces model of the company, which aims to identify and overcome the threats posed to a company by environment. This strategic approach focuses on creating barriers between the company and its surroundings in order to eliminate the threats. The second approach emphasizes the resources of the company. It stresses that each company has four types of resources at it disposal: financial resources, physical resources, human resources and organizational resources. It uses them to formulate and implement an effective strategy. In the current circumstances of constantly changing environment the organizational and human resources are becoming essential. Here, by contrast, building barriers seems to be counterproductive. Development of these resources means to emphasize the mutually 
beneficial interpersonal relationships and create effective cooperation between the company and its surrounding.

\section{Education of employees - contribution of the companies to inclusive growth}

In the search for synergic solutions that would lead to elimination of barriers and promotion of cooperation, it is necessary to identify these barriers in the first step. These barriers occur both on the side of management of the company as well as on the employees' side. On the side of the company, they are primarily related to the fact that often there is little motivation to invest in the education of employees; on the employees side they are represented by the reluctance of employees to use this offer, as well as the unwillingness or inability to transform the acquired knowledge and skills into business practice.

The first barrier on the side of the company is possibility to lose the skilled employees. When the company invests in employee training, it cannot be sure that the employee remains in the company even after the training. When such an employee leaves the company, it loses not only the resources invested into his training and potential return from this resources, but it also incurs additional costs associated with adopting a new employee. Nowadays, there is a trend to invest into the training of younger employees because of their higher performance potential, however a high fluctuation is typical for younger; it is connected to their way of life. The older employees are more willing to stay in the company for the longer period after completing the training, during which they can use the knowledge and skills resulting form invested resources.

Another barrier of the company, which we perceive in the education of employees, are expenditures on education at the time of overcoming the economic crisis. The situation with staff education has changed significantly at the time of the crisis. Many companies react primarily on the crisis by cutting the resources dedicated on education. Employee training is a longer process, whose benefits cannot often be seen immediately after training. On the other hand it is also clear that in times of crisis the spending on education is not necessary for the survival of the company. Decreased spending on education, however, can represent a significant threat for the company in the long run and also the possible loss of competitive advantage, which is mainly the results of skilled workers who are able to transform the latest knowledge to business practice. G. Elexová (2011) based on the results of research predicts, that education of employees after the crisis will be not as frequent as before the crisis. If the employee education should gain the position as it deserves as an important part of human resources management, it should be perceived as relevant and necessary for the doing business and for ensuring fulfillment of business needs. By these needs we mean for example development that will bring demonstrable positive change to current practice, motivating people to develop themselves, to make the business processes more effective, to improve productivity, to motivate and to encourage others to develop, returns to investment, stability of key employees and other.

As to the barrier in the employees' side, we see as the serious problem possible competition between employees. Employees with higher education can apply their education in better jobs within the company and it may affect other employees working at these jobs. In addition, a competition between employees and management can occur, if an employee gains higher education as a representative of the management of the company, the representative can feel threatened. Higher education can also be reason for the requirement to increase a salary that needn't be always acceptable for the employer. 
Another barrier that employees can perceive is so called crowding out low-skilled workers by employees with higher qualifications. An employee, who gains higher education, can obtain a higher degree of certainty of remaining in a current job than an employee, who does not extend his education. Increasing education is likely to increase employee productivity. Highly qualified employee can manage several operations that were previously performed by more people and many workers may become redundant in this way.

A significant barrier that reduces the effectiveness and outcomes of education is ignorance or lack of knowledge of culture and context in which learning takes place. This is risk especially for international companies. It is related primarily to universalistic conception of human resource management, namely the belief that there are principles and best practices leading to improved business performance (Vountisjärvi, 2011). This fact manifests itself mainly in post-communist countries, where even after twenty years is still a paternalistic mentality (Ryan, 2004), but not only there.

To eliminate the barriers, which restrain effective training in the company it is useful that all subjects involved are informed about the contributions, which are result of education. If the company decides to invest in training of their employees, its benefits receive not only employers but also employees and surrounding of the company. These advantages we can characterize as a positive externalities.

As to the advantages for the company, it invests to employee training mainly because it expects the increase of profits. The increase in profits on the basis of employee training may occur in several ways. Employee training can help streamline the business processes and also contribute to their optimization. In this way the company can adapt more quickly to market changes and to plan the response. Employee training can also help to use of resources more effectively and thereby reduce costs. By resources in this case we mean both sources of material character, but also financial and human resources. The more educated workers are likely to have higher labor productivity, which can contribute to reduction of the number of employees, thus saving labor costs. The training of employees brings to the company a significant competitive advantage in several areas. On the one hand, the company through qualified personnel can use the latest knowledge in the field. On the other hand, the company which educates its employees creates goodwill in its surrounding which also affects its position of the preferred employer for potential employees.

The advantages which result from the training for employees are often the reason why the employees decide to participate in financing their education. By education, an employee can broaden knowledge eventually acquire new skills that can be used in their jobs. In this way, he can increase his productivity and strengthen his position in the company. Higher qualification is often reflected in increased remuneration of employees. Finally, the education has its importance in the long run when the employee enhances his employability. Employability can be characterized as the ability to be employed, suggesting that this is something that can be created on the basis of additional investments in human capital. Fostering this kind of security has perspective for an employee in the future, as it is highly probable that in future he will change or lose his job and find himself in the position of the unemployed in the labor market. Increased education can help shorten the period of unemployment and contribute to finding a job satisfying his requirements. Thus the flexicurity approach on the company level focuses on raising the level of job security and employability. Strengthening of security of employability is directly related to individual responsibility for everything that takes place in his life. According to J. Horeháj (2008) an 
individual responsibility has moral and value dimension, but also the irreplaceable role as principle, which is a building stone of civilization.

From the perspective of company surroundings, possible benefits of employee training can be characterized as the development of social capital. J. Marasová (2008) describes it as "a surplus value, which is created by using local resources and investing in them. This contribution is a catalyst for the creation of synergy, a fundamental element of the living organic material necessary for territorial development. "The main motivation for the company to contribute to the development of this capital and to take it into account in their decisions is that" the company is not and has never been self-sufficient and independent entity independent from the outside world "(Marasová, 2008, p. 96). The company contributes significantly to the educational level of the region, but it also uses its resources. It does not relate only to the level of practical knowledge and skills, but also at the level of values and ethics. J. Simmons (2008) compares the ethical development of the company with ethical development of individuals; both depend on understanding the world around us.

In connection to education of employees, it is worth mentioning the conduct of companies the Netherlands, where the companies operating in the same industry and often in the same region, create a common fund from which they can draw resources to educate their employees. If the employee subsequently leaves the company, the resources invested in education remain in the industry. Recently, in the Netherlands there is an emphasis on the role of regions in providing training to employees. The region itself forms a compact unit, which provides space for the operation of various companies, often on the basis of the sector specialization of the region. Coordination of the education provided by the regional government helps to ensure suitably skilled workforce needed for the development of the region.

\section{European Union and the CSR support}

The European Commission is also aware of the need to involve companies in their policies. The main tool in this direction is to support the concept of corporate social responsibility. Several authors (Vountisjärvi, Rydell, Wigblad) consider flexicurity approach as one of the forms of corporate social responsibility. This theme resonates in the European Union more than a decade. In 2001 was published the Commission's Green Paper Promoting a European framework for corporate social responsibility in order to launch a wide debate on this issue. This document contains frequently cited definition which sees CSR as "concept whereby companies integrate social and environmental concerns in their business operations and in their interaction with their stakeholders on a voluntary basis" (Green Paper, 2001, p. 4). Although the definition remained the same over the past decade, we can observe certain development in further documents of the European Commission. In the Green Paper the corporate social responsibility was presented particularly as a tool to achieve profit. It means, the company responding to some pressure from the environment sends a positive signal to stakeholders and in this way it invests to its future and expects that such an activity will increase profitability.

Following the discussion started in the Green Paper, in 2002 the European Commission issued a communication entitled Corporate Social Responsibility: A business contribution to Sustainable Development. A significant shift with regard to the Green Paper is obvious, particularly, in the fact that understanding of the sense of existence of a company was extended from the narrow term of "profit" to a much broader term of "success", therefore the CSR concept is not only a tool for achieving profit, but the way of managing which leads to 
the success. The result of company's activity is not evaluated only on the basis of positive or negative economic result, but also in the context of the impact of its decisions on its stakeholders. The communication also defines the three basic features of a CSR:

- CSR is behaviour by businesses over and above legal requirements, voluntarily adopted because businesses deem it to be in their long-term interest;

- CSR is intrinsically linked to the concept of sustainable development: businesses need to integrate the economic, social and environmental impact in their operations;

- CSR is not an optional "add-on" to business core activities - but about the way in which businesses are managed. (Communication 2002).

New dimension to the understanding of corporate responsibility was brought by Communication from the Commission: Implementing the Partnership for Growth and Jobs: Making Europe a pole of excellence on Corporate Social Responsibility. The fact comes to the fore that social responsibility is mainly a matter of value orientation of the company and it depends to a large extent on the environment in which the enterprise carries on its activities and that is why it cannot be regulated on the centralised basis. Additional obligations and administrative requirements deemed to be counterproductive in connection to its conviction that for the development of the CSR concept creativity and innovativeness are needed.

Nowadays, the most important tool for support of CSR is an initiative Enterprise 2020. It is represented by set of projects coordinated by the network CSR Europe, which connects companies and NGOs dealing with CSR. The main goals of the initiative are:

- supporting the companies in building sustainable competitiveness by providing a platform for innovation and exchange of ideas;

- promote close cooperation between companies and the relevant actors involved in the effort to find new ways to work together to shape a sustainable future;

- strengthening the progressive advancement of Europe in the field of corporate social responsibility by involvement of EU institutions and the wider range of international actors.

Through the projects, the initiative is attempting to effectively draw attention to the six thematic areas that are considered to be crucial in achieving sustainable development: the supply chain and human rights, health and welfare, aging and demographic change, reporting, financial education and inclusion of groups with the lowest incomes.

\section{Conclusion}

Companies do not affect the labour market only from the position of the subject demanding the labour, but also they significantly influence the quality of human capital in the region in which they operate, primarily by investing in employee training. In this sense, they are the growth poles that support the development of the region. For this reason, it is possible to attribute the revenues derived from such investments only to the investing firm, as certain benefits are received by its employees, by the region, as well as by other companies operating in the region. It is therefore necessary both to assess such investments in a broader context and on the other hand seek opportunities for cooperation between stakeholders, which would create synergies for all involved. In this context, the promotion of ideas of corporate social responsibility seems to be very actual as it represents the cornerstone for the identification and involvement of stakeholders in various areas of business management. The challenge for the future in the context of post-crisis conditions is to focus on long-term development of the company and on the direct or indirect positive influence on business environment in which the company operates. 


\section{References}

[1] BELOT, M., J. BOONE and J. VAN OURS, 2007. Welfare improving employment protection. Economica, vol. 74, n.295, p. 381-396.

[2] BOOSLIE, P., J. PAAUWE and P. JANSEN, 2001. Human resources management and performance: lesson form the Netherlands. Interantional Journal of Human Resources Management, vol. 12, n.7, p. 1007-1125.

[3] CAZES, S. and A. NESPOROVA, 2007. Flexicurity: A relevant approach for Central and Eastern Europe. International Labour Office: Geneva.

[4] Communication from the Commission concerning Corporate Social Responsibility: A business contribution to Sustainable Development. Brussels, 2002. COM 2002/347.

[5] Communication from the Commission Europe 2020: a strategy for smart, sustainable and inclusive growth. Brussels, 2010. COM 2010/2020.

[6] DONALDSON, T. and L.E. PRESTON, 1995. The Stakejolder theory of the corporation: Concepts, evidence and implications. Academy of Management Review, vol. 20, n.1, p. 65-91.

[7] DUDOVÁ, I., S. OŠKOVÁ a V. STANEK, 2008. Ekonomická výkonnost' a systémy sociálnej ochrany. Ekonomický časopis, vol. 56, n. 4, p. 310-324.

[8] ELEXOVÁ, G., 2011. Human resources development under the conditions of the global crisis. E+M Ekonomika a Management, vol. 14, n. 3, p. 46-56.

[9] FREDMAN, S., 2004. Women at Work: The Broken Promise of Flexicurity. In Industrial Law Journal, roč. 33, č. 4. ISSN 0305-9332, s. 299-319.

[10]FRIEDMAN, M. The Social Responsibility of Business is to Increase its Profits. The New York Times magazine: http://www.umich.edu/ thecore/doc/Friedman.pdf.

[11]Green paper. Promoting a European framework for Corporate Social Responsibility. Brussels. 2001. COM 2001/366.

[12] GREINER, A. and P. FLASCHEL, 2009. Economic growth and the epmloyer of last resort: A simple model of flexicurity capitalism. Research in Economics, vol. 63, n. 2, p. 102-113.

[13]HOREHÁJ, J., 2008. Individuálna zodpovednost' a súkromné vlastníctvo v ekonomickom vzdelávaní. Ekonomické vzdelávanie $\mathrm{v}$ znalostnej ekonomike : Zborník príspevkov $\mathrm{z}$ medzinárodnej vedeckej konferencie, Ekonomická univerzita, Národohospodárska fakulta: Bratislava.

[14]HOREHÁJOVÁ, M. a J. MARASOVÁ, 2008. The institutional factors of the corporate social responsibility development in the Central European countries. Ekonomie a management, vol. 9, n. 2, p. 58-64.

[15] KNIPPENBERG, L. and E. DE JONG, 2010. Moralising the Market by Moralising the Firm: Towards a Firm-Oriented Perspective of Corporate Social Responsiblity. Journal of Business Ethics, vol.29, n.1, p. 17-31.

[16]MARASOVÁ, J., 2008. Vnútorná a vonkajšia sociálna funkcia podniku. Ekonomická fakulta UMB: Banská Bystrica.

[17]NEUMAIEROVÁ, I. a I. NEUMAIER, 2002. Vykonnost a tržní hodnota firmy. Grada Publishing: Praha. 
[18] Oznámenie Komisie, ktorým sa implementuje partnerstvo pre rast a zamestnanost': Európa ako pilier najvyššej kvality v oblasti podnikovej sociálnej zodpovednosti. Brusel, 2006. COM 2006/136.

[19]POTUŽÁKOVÁ, Z. a S. MILDEOVÁ, 2011. Systémový př́stup ke konceptu flexicurity. Politická ekonomie, vol. 59, n. 2, p. 224-241.

[20]RYAN L.V., 2006. Current Ethical Issues in Polish HRM. Journal of Business Ethics, vol. 66, n. 2-3, p. 273-290.

[21]RYDELL, A. and R. WIGBLAD, 2011. A company- level flexicurity model during the restructuring processes. Transfer: European Review of Labour and Research, vol. 17, n.4, p. 547-562.

[22] SIMMONS, J., 2008. CSR and management. Ethics and morality in human resources management. Social responsibility journal, vol. 4, n. 1-2, p.8-23.

[23] SMITH, A., 2001. Pojednání o podstatě a pưvodu bohatství národů. Liberálni institut: Praha.

[24]URAMOVÁ, M., 2004. Trh práce a jeho nedokonalosti. Studia oeconomica 23. Univerzita Mateja Bela, Ekonomická fakulta v spolupráci s OZ Ekonómia: Banská Bystrica.

[25] VOUNTISJÄRVI, T., 2006. The European context for corporate social responsibility and human resources management: an analysis of the largest Finnish companies. Business Ethics: A European Review, vol.15, n.3, p. 271-291.

[26] WILTHAGEN, T. and F. TROS, 2004. The Concept of „Flexicurity “: A new approach to regulating employment and labour markets. Transfer: European Review of Labour and Research, vol. 10, n. 2, p. $166-186$. 